Montreal, ${ }^{15}$ but a recent review of evidence for the United Kingdom $^{16}$ found no consistent relation. The group of diabetics in this study was small and does not provide unequivocal evidence for a relation between the disease and social class. Because the aetiological implications of such an association are great, however, the data suggest the need for larger studies to define unequivocally any relations that may exist. Meanwhile, the likelihood that childhood diabetics are a socially advantaged group should be taken into account in interpreting other studies on these children, particularly those based on outcomes such as growth, on which social class differences have an effect. ${ }^{17}$

The aetiological implications of a rising prevalence of diabetes are consistent with those of a positive association with social class. The rapid and consistent increase in prevalence implies the influence of environmental rather than purely genetic factors. One of these factors might well be the dietary changes associated with a rising per caput income in the Western world, which would manifest itself first in the higher social classes. From the point of view of health service planners there are other serious implications. In the absence of radical advances in treatment the juvenile diabetics of today are bound to become major consumers of ophthalmological and renal services in the future; planners will need to take these changes into account if the needs of these diabetic children are to be met.

The health aspect of the 10 year follow up was funded by a grant from the Department of Health and Social Security to the department of child health, University of Bristol. Additional financial support was received from the National Institutes of Health, USA. We gratefully acknowledge the cooperation of all specialists in community medicine, community medical officers, and health visitors who made this study possible, and the participating children and their parents.

\section{References}

1 North AF, Gorwitz K, Sultz HA. Evidence of a secular increase in the incidence of juvenile diabetes mellitus. $\mathcal{F}$ Pediatr 1977;91:706-10.

${ }^{2}$ Cohen T. Juvenile diabetes in Israel. Isr f Med Sci 1971;7:1558-61.

${ }^{3}$ Kovisto VA, Akerblom HK, Wasz-Hockert O. The epidemiology of juvenile diabetes mellitus in northern Finland. Nordic Council Arctic Medical Research Report 1976;No 15:58-65.

${ }^{4}$ Lestradet $\mathrm{H}$, Besse J. Prevalence and incidence of juvenile diabetes in children and adolescents. Bulletin of the International Study Group in Diabetic Children and Adolescents 1977 ; No 1:5-6.

${ }^{5}$ Pinelli L, Tato L, Andrelte A, et al. The epidemiology of childhood diabetics in northern Italy. Bulletin of the International Study Group in Diabetic Children and Adolescents 1977; No 1:6-9.

${ }^{6}$ Wadsworth $M$, Jarret $R$. Incidence of diabetes in the first 26 years of life. Lancet $1974 ;$ ii :1172-4.

${ }^{7}$ Calnan H, Peckham C. Incidence of insulin dependent diabetes in the first 16 years of life. Lancet $1977 ; \mathrm{i}: 589-90$

8 Adelstein AM. National statistics. Postgrad Med $\mathcal{F}$ 1975;51,suppl 2:57-67.

${ }^{9}$ Chamberlain R. British births 1970. Vols 1 and 2. London: Heinemann Medical, 1975 (vol 1), 1978 (vol 2).

${ }^{10}$ Office of Population Censuses and Surveys. Classification of occupations. London: HMSO, 1980.

${ }^{11}$ Fogelman K. Britain's 16 year olds. London: National Children's Bureau, 1976:1-16.

${ }^{12}$ Douglas JWB, Blomfield JM. Millbank Mem Fund $Q$ 1956;34:227.

${ }^{13}$ Bloom A, Hayes $T$, Gamble D. Register of newly diagnosed diabetic children. Br Med $\mathcal{F} 1975$;iii:580-3.

14 Christy M, Christan B, Molak A, Nerup J. Diabetes mellitus and month of birth. Lancet 1982 ;ii:216.

${ }_{15}$ West R, Belmont E, Colle MP, et al. Epidemiologic survey of juvenile onset diabetes in Montreal. Diabetes 1979;28:690-3.

${ }^{16}$ Anonymous. Diabetes mellitus and socioeconomic factors [Editorial]. Lancet $1982 ;$ ii $: 530$.

17 Rona RJ, Swan AV, Altman DG. Social factors and height of primary school children in England, Wales, and Scotland. F Epidemiol Community Health $1978 ; 32: 147-54$.

(Accepted 1 March 1983)

\title{
Decline in mortality from coronary heart disease in Finland from 1969 to 1979
}

\author{
JUKKA T SALONEN, PEKKA PUSKA, THOMAS E KOTTKE, JAAKKO TUOMILEHTO, \\ AULIKKI NISSINEN
}

\begin{abstract}
The trends in mortality from coronary heart disease in the 1970s and the differences in trends between counties within Finland were calculated from official mortality statistics among the population aged 35 to 64 years. During this period coronary mortality declined by a mean of $1.1 \%$ for men and $2.3 \%$ for women annually in the whole of Finland. A community based cardiovascular
\end{abstract}

\section{University of Kuopio, Kuopio, Finland}

JUKKA T SALONEN, MD, principal of research institute of public health JAAKKO TUOMILEHTO, MD, acting professor of community health

Department of Epidemiology, National Public Health Institute, Helsinki, Finland

PEKKA PUSKA, MD, director

AULIKKI NISSINEN, MD, special research investigator

\section{Department of Medicine and Laboratory of Physiological Hygiene, University of Minnesota, Minneapolis, USA}

THOMAS E KOTTKE, MD, assistant professor

Correspondence to: Professor Jukka T Salonen, Research Institute of Public Health, Box 40, 70101 Kuopio 10, Finland. control programme was started in 1972 in North Karelia, a county in the east of Finland. The decline in coronary mortality in this county between 1969 and 1979 was $24 \%$ in men and $51 \%$ in women. The decline in the rest of Finland over the same period was $12 \%$ in men and $24 \%$ in women. The decline in North Karelia was greater than that in other counties of Finland for both men and women and that difference exceeded random variation, with over $\mathbf{9 5 \%}$ likelihood for both sexes. Even with adjustment for rates before 1974 with cross-county multiple regression analyses the difference persisted.

Although further studies are needed, the changes in coronary mortality in North Karelia suggest that the preventive programme has been effective.

\section{Introduction}

Trends in mortality from coronary heart disease have varied during the past two decades in different countries of the world. Declining trends have been observed in some industrialised countries in the $1970 s^{1-11}$ Preliminary evidence suggests that coronary mortality has decreased in Finland in middle aged men and women. ${ }^{12-15}$ Regional differences in coronary mortality 
within Finland have been observed since the 1940s, the highest rates being in the east and lowest in the south west. ${ }^{16}{ }^{18}$ In 1972 a community based programme was started to reduce the high risk factors and rates for cardiovascular disease in North Karelia, an eastern Finnish county, ${ }^{19}$ but the evaluation of the first five years (1972-7) of the North Karelia project did not show any differences in the trends between North Karelia and Kuopio, the reference area for the project. ${ }^{20}$ These analyses did not compare North Karelia with other areas or with the whole country. We now present the latest available data to estimate the magnitude of the decline in coronary mortality in Finland in the 1970s and to explore the differences in trends between areas within Finland, with special reference to the county of North Karelia.

\section{Methods}

The data on deaths for the disease category A83 (410-414) of the International Classification of Diseases, Injuries, and Causes of Death (ICD) were obtained from the central statistical office of Finland for the years 1969 to 1979 . These were stratified into three age groups (35-44, 45-54, and 55-64) and by sex. The diagnoses on the individual death certificates had been reviewed according to WHO guidelines and recertified by the signer if necessary. The eighth ICD revision, adopted in Finland in 1969, was used for the entire study period. The population data for 1970 are based on the census, and those for other years are based on registration of births, deaths, and migration.

The mid-year populations were used as denominators in computing the annual mortality. Death rates were standardised for age by the direct method, using the population distributions of men and women in the whole country in 1969 as the standards. Regression slopes were tested for significance with the Mantel extension test. ${ }^{21}$ To test differences between regression slopes the non-null standard errors of the slopes were estimated. The confidence intervals of the changes based on regressions were computed on the assumption of asymptotic normality of the estimates. The confidence intervals and, in some cases, the statistical significances for the trends were used to describe the extent of random variation (possibility of chance) in the estimates rather than to make statistical inferences about the sampling frame.

The difference in the change in the slope of age standardised mortality between North Karelia and the other 10 counties of Finland was estimated and tested for significance with multiple time series regression analysis. The slopes were compared for the time intervals 1969-73 and 1974-9. Although the programme was started in 1972, a latency of two years was assumed before any possible effects of the programme on mortality could appear; data for the years 1969 to 1973 were therefore assumed to reflect the situation before any effect of the programme. The rates were transformed to correct for autoregression as suggested by Simonton. ${ }^{22}$ The data for men and women were included in the same analysis to increase the number of statistical units.

\section{Results}

The age standardised annual mortality from coronary heart disease for men and women aged 35 to 64 years in the whole of Finland declined during the period from 1969 to 1979 . In 1969 coronary mortality was 483 per 100000 for men and 97 per 100000 for women, whereas in 1979 the rates were 390 for men and 77 for women. The reduction in age standardised coronary mortality, estimated by the slope of regression, was $12^{\circ}{ }^{\circ}$ for men over the 11 years and $26^{\circ}{ }^{\circ}$, for women. Thus the average annual decrease during this period was $1.1 \%$ for men and $2.3 \%$ for women. For men the reduction was steeper during 1974-9 than during 1969-73. In women the rate of change declined slightly from 1969-73 to 1974-9.

During 1969-79 coronary mortality declined among men in all counties but one. The exception was a county in south west Finland with an initially low coronary mortality (fig 1). The greatest decline for both men and women took place in North Karelia. The coronary mortality for men fell by $24^{\circ},\left(95^{\circ}\right.$, confidence interval, $12-36^{\circ} \%$ ) in North Karelia during the whole period. The second largest decline $\left(22^{\circ}{ }_{0}\right)$ during the whole period in men occurred in Vaasa, a county with low coronary mortality. The decline in coronary mortality in Kuopio, the reference area for the evaluation of the North Karelia project, was the third greatest for the whole period, $21^{\prime \prime \prime}$ (fig 1). To assess more closely the changes among men in North Karelia, the rates were compared with those in Kuopio and with those of the whole country except North Karelia. Figure 2 shows the annual age standardised coronary mortality in men aged 35-64 as well as the fitted regression lines for North Karelia and all other counties of Finland.



FIG 1-Age standardised coronary mortality in 1969 for men aged $35-64$ in the 11 counties of Finland (first figure) and regression based 11 year decline $(\%)$ (second figure) with $95 \%$ confidence intervals (in parentheses).

The decline in age standardised coronary mortality for men during 1969-79, estimated by the slope of linear regression, was $24^{\circ} \%$ in North Karelia, $21 \%$ in the county of Kuopio, and $12 \%$ in the whole of Finland less North Karelia (table I). The respective declines for women were $51^{\circ} \%$ in North Karelia, $36^{\circ}$ in the county of Kuopio, and $24^{\circ}$ in the rest of Finland (table $I$ ). The difference in the linear regression slopes between North Karelia and other parts of Finland exceeded random variation for both men (standardised normal deviate (Z) $2.06, p<0.05)$ and for women $(Z=3.34, p<0.001)$. The difference in the slopes for North Karelia and Kuopio was within random variation for men but exceeded random variation for women $(Z=1.97$, $\mathrm{p}<0.05)$.

The rate of decline in coronary mortality for men increased from 




FIG 2-Age standardised annual coronary mortality (per $10^{5}$ ) in men aged 35-64 years in North Karelia (") and 10 other counties of Finland from 1969 to 1979 with fitted regression lines $(-)$. the annual average of $2 \cdot 5 \%$ for $1969-73$ to $3 \cdot 7 \%$ for $1974-9$ in North Karelia (table I). There was also some acceleration in the decline in the reference area and the whole of Finland except North Karelia, but the average annual decline in men for 1974-9 was significantly greater for North Karelia than for the rest of Finland $(Z=2 \cdot 25, p<0.05)$. For women, the rate of decline slowed down from 1969-73 to 1974-9 in North Karelia, the reference area, and all Finland less North Karelia (table I). The differences between North Karelia and the remainder of Finland for total and cardiovascular mortality were in the same direction but smaller and not significant.

Table II presents the annual age standardised coronary mortality ratios (with 1974 rates as denominators) in men in North Karelia, Kuopio, and all Finland from 1974 to 1979. The decline in North Karelia $(p<0.05)$ and in the whole country $(p<0.001)$ exceeded random variation.

In the multiple cross-county time series regression analysis age standardised mortality had a significant negative partial regression on the term for the three way interaction of county (North Karelia $v$ other), year, and period in sexes combined and in men and women separately. This indicated a greater acceleration of the decline in mortality from coronary heart disease, cardiovascular disease, and all disease from 1969-73 to 1974-9 in North Karelia than in the other counties of Finland even with control for differences in mortality between counties in 1969-73 (tables III and IV). The result was confirmed in identical analyses with autoregression-corrected rates.

TABLE I-Age standardised coronary mortality in 1969, average annual regression based decline (as \% of 1969 rate) and overall decline from 1969 to 1979 in men and women aged 35-64 years in North Karelia, Kuopio, and Finland less North Karelia. (Figures in parentheses are $95 \%$ confidence intervals)

\begin{tabular}{|c|c|c|c|c|c|c|}
\hline & \multicolumn{2}{|c|}{ North Karelia } & \multicolumn{2}{|c|}{ Kuopio } & \multicolumn{2}{|c|}{ Finland less North Karelia } \\
\hline & Men & Women & Men & Women & Men & Women \\
\hline $\begin{array}{l}\text { Annual rate in } 1969 \text { (per } 100000) \\
\text { Regression based estimate for } 1969 \text { rate } \\
\text { Mean annual decline }\left({ }^{\circ}\right) \text { : }\end{array}$ & $\begin{array}{l}688 \\
663\end{array}$ & $\begin{array}{l}149 \\
140\end{array}$ & $\begin{array}{l}578 \\
606\end{array}$ & $\begin{array}{l}120 \\
125\end{array}$ & $\begin{array}{l}483 \\
501\end{array}$ & $\begin{array}{r}97 \\
103\end{array}$ \\
\hline $\begin{array}{l}1969-73 \\
1974-9 \\
1972-9 \\
1969-79 \\
\text { Overall decline from } 1969 \text { to } 1979(\%)\end{array}$ & $\begin{array}{l}2 \cdot 5(5 \cdot 1) \\
3 \cdot 7(1 \cdot 2) \\
2 \cdot 0(1 \cdot 5) \\
2 \cdot 2(1 \cdot 1) \\
24(12)\end{array}$ & $\begin{array}{l}7 \cdot 7(4 \cdot 0) \\
2 \cdot 2(3 \cdot 4) \\
2 \cdot 3(1 \cdot 9) \\
4 \cdot 3(1 \cdot 4) \\
51(17)\end{array}$ & $\begin{array}{r}1.2(6.5) \\
1.9(2.3) \\
1.4(1.4) \\
1.9(1.3) \\
21(14)\end{array}$ & $\begin{array}{l}6 \cdot 0(3 \cdot 3) \\
1.8(1 \cdot 4) \\
1.5(7 \cdot 8) \\
3 \cdot 1(1 \cdot 0)^{*} \\
36(11)^{*}\end{array}$ & $\begin{array}{l}0 \cdot 8(3 \cdot 1) \\
1 \cdot 7(2 \cdot 2)^{*} \\
1 \cdot 2(1 \cdot 4) \\
1 \cdot 1(0 \cdot 9)^{*} \\
12(10)^{*}\end{array}$ & $\begin{array}{l}1 \cdot 5(3 \cdot 9) \\
1 \cdot 2(2 \cdot 4) \\
2 \cdot 1(1 \cdot 6) \\
2 \cdot 2(1 \cdot 0)^{* * *} \\
24(11)^{* * *}\end{array}$ \\
\hline
\end{tabular}

${ }^{*}$ Difference from North Karelia in relation to random variation indicated as $*$ if $p<0.05, * *$ if $p<0.01$ and $* * *$ if $p<0.001$.

TABLE II-Age standardised mortality ratios (in relation to 1974 rates) for ischaemic heart disease (ICD 410-414) in men aged 35-64 years in North Karelia, Kuopio, and all Finland, 1974-69

\begin{tabular}{llllllll} 
& & & & & & \\
& 1974 & 1975 & 1976 & 1977 & 1978 & 1979 & $\begin{array}{c}\chi \text { for } \\
\text { linear trend }\end{array}$ \\
\hline North Karelia & 1.00 & 0.94 & 0.87 & 0.87 & 0.86 & 0.78 & $-2.25^{*}$ \\
Kuopio & 1.00 & 1.01 & 1.06 & 0.92 & 0.98 & 0.88 & -1.43 \\
Whole country & 1.00 & 0.98 & 1.01 & 0.95 & 0.89 & 0.89 & $-4.58^{* * *}$ \\
\hline
\end{tabular}

$*$ p. $0.05, * * *$ p. $\cdot 0 \cdot 001$

\section{Discussion}

The purpose of this analysis was to assess recent changes in coronary mortality in Finland with special attention to North Karelia, the site of a comprehensive prevention programme since 1972. Earlier reports have indicated a decline in coronary mortality in Finland as a whole and in North Karelia, but these reports were based on shorter time periods and did not indicate differential changes in mortality. ${ }^{12-14} 2023 \mathrm{We}$ used the most

TABLE III-Partial regression of age standardised coronary, cardiovascular, and total mortality for age range 35-64 years on sex (1 for men, 0 for women), area (1 for North Karelia, 0 for other counties), and interaction of area, year, and period (1 for 1974-9, 0 for 1969-73) in 11 counties of Finland, 1969-79

\begin{tabular}{|c|c|c|c|c|c|c|}
\hline & \multicolumn{2}{|c|}{ Coronary mortality } & \multicolumn{2}{|c|}{ Cardiovascular mortality } & \multicolumn{2}{|c|}{ Total mortality } \\
\hline & Partial coefficient & Increase in $\mathrm{r}^{2}$ & Partial coefficient & Increase in $\mathrm{r}^{2}$ & Partial coefficient & Increase in $\mathrm{r}^{2}$ \\
\hline $\begin{array}{l}\text { Sex } \\
\text { Differencet in level in first period } \\
\text { Differencet in change of slope between periods } \\
\text { Constant term }\end{array}$ & $\begin{array}{l}3950 \cdot 0^{* * * *} \\
902 \cdot 1^{* * * *} \\
-77 \cdot 7^{*} \\
4826 \cdot 0\end{array}$ & $\begin{array}{l}0.913 \\
0.008 \\
0.002\end{array}$ & $\begin{array}{l}4553 \cdot 4^{* * * *} \\
1359 \cdot 4^{* * * *} \\
-134 \cdot 4^{* * *} \\
6505 \cdot 7\end{array}$ & $\begin{array}{l}0.883 \\
0.012 \\
0.004\end{array}$ & $\begin{array}{l}7840 \cdot 4^{* * *} \\
1531 \cdot 9^{* * *} \\
-145 \cdot 7^{*} \\
12421 \cdot 4\end{array}$ & $\begin{array}{l}0.909 \\
0.005 \\
0.002\end{array}$ \\
\hline
\end{tabular}

+Between North Karelia and 10 other continental counties, $\mathrm{n}=242$. Statistical significance shown as ${ }^{*} \mathrm{p} \cdot 0 \cdot 05,{ }^{* *} \mathrm{p} \cdot 0 \cdot 01,{ }^{* * *} \mathrm{p} \cdot 0 \cdot 001$.

TABLE IV-Partial regression of age standardised coronary, cardiovascular, and total mortality for men and women aged 35-64 years on area (1 for North Karelia, 0 for other counties) and interaction of area, year, and period (1 for 1974-9, 0 for 1969-73) in 11 counties of Finland, $1969-79$

\begin{tabular}{|c|c|c|c|c|c|c|c|c|c|c|c|c|}
\hline & \multicolumn{4}{|c|}{ Coronary mortality } & \multicolumn{4}{|c|}{ Cardiovascular mortality } & \multicolumn{4}{|c|}{ Total mortality } \\
\hline & \multicolumn{2}{|c|}{ Partial coefficient } & \multicolumn{2}{|c|}{ Increase in $r^{2}$} & \multicolumn{2}{|c|}{ Partial coefficient } & \multicolumn{2}{|c|}{ Increase in $r^{2}$} & \multicolumn{2}{|c|}{ Partial coefficient } & \multicolumn{2}{|c|}{ Increase in $r^{2}$} \\
\hline & Men & Women & Men & Women & Men & Women & Men & Women & Men & Women & Men & Women \\
\hline $\begin{array}{l}\text { Difference in level in first period } \dagger \\
\text { Difference in change of slope }\end{array}$ & $1531 \cdot 6^{* * *}$ & $272 \cdot 7^{* * *}$ & $0 \cdot 158$ & 0.039 & $2060 \cdot 0 * * *$ & $658 \cdot 9 * * *$ & $0 \cdot 169$ & 0.035 & $2486 \cdot 6 * * *$ & $577 \cdot 1^{*}$ & $0 \cdot 107$ & 0.013 \\
\hline $\begin{array}{l}\text { between periods }{ }^{\dagger} \\
\text { Constant term }\end{array}$ & $\begin{array}{l}-114 \cdot 3^{*} \\
4779 \cdot 7\end{array}$ & $\begin{array}{l}-41 \cdot 0^{* *} \\
992 \cdot 3\end{array}$ & 0.026 & 0.057 & $\begin{array}{l}-158 \cdot 1^{*} \\
6449 \cdot 0\end{array}$ & $\begin{array}{l}-110 \cdot 8^{* * *} \\
2009 \cdot 0\end{array}$ & 0.030 & 0.082 & $\begin{array}{r}-185 \cdot 0 \\
12346 \cdot 3\end{array}$ & $\begin{array}{l}-106 \cdot 3^{*} \\
4656 \cdot 1\end{array}$ & 0.017 & 0.046 \\
\hline
\end{tabular}

${ }^{*} \mathrm{p} \cdot 0 \cdot 05, * * \mathrm{p} \cdot 0 \cdot 01,{ }^{* * *} \mathrm{p} \cdot 0 \cdot 001$

+Difference between North Karelia and 10 other counties, $(n=121)$. 
recently available official disease-specific data on death. The first year chosen for the analyses was 1969, as that was the first year of the eighth ICD revision. The fact that this revision has been used in Finland since 1969 has allowed for assessment of changes several years before the project and has also allowed the changes to be followed up to the end of the 1970s. Several authors have speculated that there may be a time lag between change in risk factors and change in disease mortality. ${ }^{15} 2425$ The available data allow analyses to the changes in 1974-9, two years after the start of the preventive programme when possible effects might start to emerge. ${ }^{15}$

The results show an average annual decline in coronary mortality in Finland during the 1970 s of $1 \%$ in men and $2 \%$ in women in the age range 35-64 years. During this period the highest coronary mortality in both men and women was in 1971 . From 1974 onwards the coronary mortality declined fairly constantly. Thus most of the change observed in men actually took place from 1974 to 1979.

The decline in coronary mortality over the whole decade, and especially in its first years, was somewhat greater in the economically developed counties in the south and west of Finland. The initial rates were also lower there. Exceptions to this pattern are the two eastern counties of North Karelia and Kuopio, where the decline was among the greatest in the county. Only Turku and Pori in the west experienced an increase in coronary mortality for men. In the last half of the decade the greatest decline was observed in North Karelia in the east and in Vaasa in the west. Thus the trends do not support Valkonen and Niemi's hypothesis that the decline in Finland started first in the most developed (south western) areas and last in the less developed (eastern and northern) areas with a gradient from west to east. ${ }^{13}{ }^{26}$ Nor do the trends suggest that the magnitude of the changes would be related to the initial level

During 1974-9 the counties with the greatest decline in coronary death rates were North Karelia and Vaasa. Here again the initial levels were quite different: high in North Karelia and low in Vaasa. During this period a greater decline was also observed in North Karelia than in Kuopio. We have previously reported the changes in cardiovascular morbidity and mortality from 1972 to 1977 in North Karelia and Kuopio. ${ }^{20}$ During that period no differences were observed between North Karelia and Kuopio in mortality from coronary (ICD 410-414) or cardiovascular (ICD 390-458) disease, despite a larger decline in risk factors in North Karelia. ${ }^{27}$ It was then suggested that the five year monitoring period was too short to show any effects of the programme on mortality. It now appears that the trend in coronary mortality in North Karelia deviated significantly not only from that for the whole country but also from that for Kuopio.

Changes in coronary mortality may be the result of changes in diagnostic practice, so we analysed the trends for cardiovascular mortality. The patterns of change for cardiovascular and for total mortality are similar to those for coronary mortality; it is therefore unlikely that changes in diagnostic habits had an appreciable influence on the trends in coronary mortality reported here. If anything, the community myocardial infarction register in North Karelia ${ }^{20}$ would have led to a decrease in the proportion of false negatives in the assignment of death from coronary heart disease.

Our results support the contention that a long period of observation is necessary to assess the effect of a preventive programme on mortality. In this case the most favourable trends started to emerge in North Karelia only after 1974. Although further studies are needed, we think that the differences in coronary mortality between North Karelia and the rest of the country reflect an effect of the preventive programme in North Karelia. Continued follow up may show further benefits of the programme. The intense national activity, however, inspired to a great deal by the project, may minimise further differences in rates of cardiovascular disease between North Karelia and the rest of the country. academic award IK07-HL00662, BSRG No 2-S 07-RR05 448-20 and by a grant from the Academy of Finland.

\section{References}

' Gillum RF, Blackburn H, Feinleib M. Current strategies for explaining the decline in ischemic heart disease mortality. $\mathcal{F}$ Chron Dis $1982 ; 35$ 467-74

2 Pisa Z, Uemura K. Trends of mortality from ischaemic heart disease and other cardiovascular diseases in 27 countries, 1968-1977. World Health Stat $Q 1982 ; 35$

${ }^{3}$ Anonymous. Falling mortality in coronary heart disease (Editorial). $\mathrm{Br}$ Med F 1982;284:1505-6.

4 Marmot MG, Booth M, Beral V. Changes in heart disease mortality in England and Wales and other countries. Health Trends $1981 ; \mathbf{1 3}: 33-8$.

${ }^{5}$ Dobson AJ, Gibberd RW, Wheeler DJ, Reeder SR. Age specific trends in mortality from ischaemic heart disease and cerebrovascular disease in Australia. Am F Epidemiol $1981 ; 113: 407-12$

${ }^{6}$ Beaglehole R, Hay DR, Foster FH, Sharpe DN. Trends in coronary heart disease mortality and associated risk factors in New Zealand. NZ Med $\mathcal{F}$ $1981 ; 685: 371-5$

Dwyer T, Hetzel BS. A comparison of trends of coronary heart disease mortality in Australia, USA and England and Wales with reference to three major risk factors-hypertension, cigarette smoking and diet. Int 7 Epidemiol 1980;9:65-71.

"Havlik RJ, Feinleib M, eds. Proceedings of the conference on the decline in coronary heart disease mortality. Bethesda, Maryland: Public Health Service, National Institutes of Health, 1979; NIH publication No 79 1610 .

'Ovtarov VK, Bystrova VA. Present trends in mortality in the age group 35-64 in selected developed countries between 1950-1973. World Health Stat $Q 1978 ; 31: 208-346$

10 Florey CV, Melia RJW, Darby SC. Changing mortality from ischaemic heart disease in Great Britain 1968-76. Br Med 7 1978;i:635-7.

"Stern MP. The recent decline in ischemic heart disease mortality. Ann Intern Med 1979;91:630-40.

Valkonen T, Niemi M-L. Sepelvaltimokuolleisuuden alueelliset erot Suomessa (Regional differences of coronary mortality in Finland). Suomen Lääkärilehti 1978;26:1968-73.

13 Valkonen T, Niemi M-L. Miesten kuolleisuuden kehitys läänin ja kuolemansyyn mukaan Suomessa vuosina 1961-75 (The development of male mortality by county cause of death in Finland in 1961-75). Helsinki : University Department of Sociology, 1980; working papers No 12.

14 Pyörälä K, Valkonen $T$. The high ischaemic heart disease mortality in Finland-international comparisons, regional differences, trends and possible causes. In : Boström H, Ljungstedt W, eds. Scandia international symposia. Medical aspects of mortality statistics. Stockholm: Almqvist and Wiksell, 1981:37-57.

15 Salonen JT, Vohlonen I. Longitudinal cross-national analysis of coronary mortality. Int $\mathcal{f}$ Epidemiol $1982 ; 11: 229-38$.

${ }^{6}$ Kannisto V. Kuolemansyyt väestöllisinä tekijöinä Suomessa (Causes of death as demographic factors in Finland). Kansantaloudellisia tutkimuksia $X V$. Helsinki, 1974.

1: Puska P. Sydan- ja verisuonitautikuolleisuuden alueelliset erot Suomess (Regional differences in CVD mortality in Finland). Suomen Lääkärileht $1972 ; 27: 3071-5$.

${ }^{1 *}$ Leppo K, Lindgren J, Ritamies M. Mortality trends in Finland in the 1960's. In: Yearbook of Population Research in Finland, XII, 1971. Helsinki: Population Research Institute, 1972.

19 Puska P, Tuomilehto J, Salonen JT, et al. Community control of cardiovascular diseases-the North Karelia Project: evaluation of a comprehensive community programme for control of cardiovascular disease in 1972-77 in North Karelia. Copenhagen: WHO/EURO, 1981.

"Salonen JT, Puska P, Mustaniemi H. Changes in morbidity and mortality during comprehensive community programme to control cardiovascular disease during 1972-7 in North Karelia. Br Med f 1979;ii:1178-83.

${ }^{21}$ Mantel N. Chi-square tests with one degree of freedom: extension of the Mantel-Haenszel Procedure. Fournal of the American Statistical Association 1963;58:690-700.

: Simonton DK. Cross-sectional time-series experiments: some suggested statistical analyses. Psychol Bull 1977;84:489-502.

23 Salonen JT. Primary prevention of sudden coronary death: A communitybased program in North Karelia, Finland. Ann NY Acad Sci 1982; $382: 423-37$.

-4 Kuller L.H. Epidemiology of cardiovascular diseases: current perspectives. Am f Epidemiol 1976;104:425-62.

Rose G. The incubation period of coronary heart disease. Eur Heart 7 $1982 ; 3$, suppl B:18.

-6 Valkonen T, Niemi M-L. Decline of mortality from cardiovascular diseases in North Karelia. Br Med 7 1980;280:46.

Salonen JT, Puska P, Kottke TE, Tuomilehto J. Changes in smoking, serum cholesterol and blood pressure levels during a community-based cardiovascular disease prevention program-the North Karelia Project. Am ₹ Epidemiol 1981;114:81-94 